\title{
NAAR DE MEETBAARHEID \\ VAN EEN RECHTVAARDIGE VERDELING
}

DOOR

PROF. DR. J. TINBERGEN *

\section{r. DRAAGWIJDTE VAN HET VRAAGSTUK}

Sinds eeuwen heeft het vraagstuk van de rechtvaardigheid de mensheid beziggehouden. Op sociaal-economisch gebied ging het daarbij om de vaststelling van wat een 'rechtvaardige prijs' zou zijn, of wat een 'rechtvaardige verdeling' van de lusten en lasten die het maatschappelijk bestel verwerkelijkt. Zou men zich een ogenblik alleen met de lusten bezighouden, dan zou in het sociaal-economische veld gesproken kunnen worden van een rechtvaardige inkomensverdeling. Maar de probleemstelling kan beter in minstens twee opzichten breder worden geformuleerd. Eensdeels gaat het niet alleen om het inkomen, maar om de daaruit verkregen bevrediging; anderdeels gaat het niet alleen om de positieve voldoening die men aan een inkomen ontleent, maar ook om de ten dele positieve, ten dele negatieve invloed van de lasten, waaronder de verantwoordelijkheden, die verbonden zijn aan het verkrijgen van het inkomen.

De vraag wat een rechtvaardige verdeling is, is het onderwerp geweest dat grote tegenstellingen in het leven heeft geroepen tussen uiteenlopende groepen in de samenleving, met name tussen belangrijke politieke stromingen. Deze stromingen werden gevoed door grote denkers die zich bewogen op verschillende gebieden van wetenschap en van moraal of ethica. Onder de wetenschapsbeoefenaren die in het bijzonder de vraag voorgelegd kregen van rechtvaardigheid in de verdeling waren vooral economisten, sociologen en rechtsfilosofen. ${ }^{1}$ De antwoorden die in de loop der eeuwen gegeven zijn waren veelal onbevredigend. Een der antwoorden waarover niet veel moeilijkheden rijzen kan worden samengevat als 'gelijke monniken, gelijke kappen'.

* It affords the Board of Editors gteat pleasure to publish this paper by one of their members. This gives the Board the opportunity, also on behalf of the readers of $D e E c o-$ nomist, to congratulate Professor Tinbergen most cordially upon his 70th birthday, which he celebrated on 12th April, 1973.

1 Voor een recent overzicht door een aantal deskundigen van de eerste rang zie men ook: L'égalité, dl. I; études publiées par H. Buck, P. Foriers, Ch. Perelman, Brussel 1971. 
De moeilijkheid komt, wanneer de kern van het vraagstuk wordt gesteld: maar wat te doen voor ongelijke 'monniken'? Een ander aspect van de onbevredigdheid die de antwoorden van wetenschapsvertegenwoordigers veroorzaakten, is dat geen enkele wetenschap alleen een antwoord heeft; en dat eigenlijk het metawetenschappelijk denken dat ik nu maar aanduid met de woorden moraal of ethica er ook aan te pas moet komen. Bovendien is het vraagstuk duidelijk van een kwantitatief karakter: het gaat om cijferschalen.

De draagwijdte van het antwoord is ontzaglijk. Als men er werkelijk in zou slagen, om een controleerbare en voor een aanzienlijke meerderheid aanvaardbare maatstaf aan te geven, zou er een betere methode van besluitvorming over de al dan niet rechtvaardigheid van de inkomensverdeling gevonden zijn dan de thans in hoofdzaak gebruikte. De uiterste voorbeelden van de thans gebruikte methoden zijn het oordeel door een meerderheidsbesluit in een vertegenwoordigend lichaam en het oordeel van een door zichzelf opgelegde élite. Zo immers kan men het stelsel van aan de ene kant parlementaire democratieën en aan de andere kant van autoritaire regeringen kenmerken. Dat autoritaire regeringen een goede oplossing zijn om een rechtvaardige verdeling te bereiken, wordt bij ons niet door veel mensen geloofd. Maar velen denken wel, dat door een meerderheidsbesluit de beste oplossing wordt verkregen. Hoe staat het echter, wanneer de meerderheid van een bepaalde maatregel per persoon maar een klein nadeel ondervindt, terwijl de minderheid per persoon een groot nadeel lijdt? Dan is de meerderheidbeslissing niet juist. En dan zouden we bij een objectieve meting van ieders welzijn nieuwe mogelijkheden aanboren van vèrstrekkende betekenis.

Ook de te sterke nadruk die de Marxistische theorieën leggen op de 'uitbuiting' door kapitaal in de beperkte zin, doordat zij de 'uitbuiting' door menselijk kapitaal buiten beschouwing laten, zou door de hier verdedigde methode kunnen worden gecompenseerd.

Het komt mij voor dat ik een methode heb ontwikkeld die enig perspectief biedt om te komen tot een allengs meer objectieve meting van het individuele en sociale welzijn. Het is de bedoeling van dit opstel om eerst het wezen van deze methode te beschrijven; vervolgens enkele eenvoudige, en zeer voorlopige toepassingen te vermelden en tenslotte het programma van toekomstig onderzoek aan te geven dat geleidelijk tot een toenemende betrouwbaarheid van de uitkomsten kan leiden. 
II. NOODZAAK EN AARD VAN DE VEREISTE INTERDISCIPLINAIRE AANPAK

Zoals al opgemerkt, kan het vraagstuk van de rechtvaardige verdeling niet worden opgelost door een der thans bestaande wetenschappen. Op zijn minst is de samenwerking vereist van filosofen, economen en ethici. Zoals ik al even aanduidde, is het voor mij de vraag of men de ethica als een wetenschap kan beschouwen; ik zou haar een wijdere strekking willen toekennen. $Z$ ij moet door de natuur van haar onderwerp denkwijzen gebruiken die verder reiken dan waarneming en logische afleiding. Men kan er over twisten of andere wetenschappen van dit verder reikende element, laten we zeggen, de intuitie, in eenzelfde mate gebruik maken of behoeven te maken.

De filosofie of methodenleer is benodigd bij het beoefenen van elke wetenschap. $\mathrm{Zij}$ behandelt de rollen die bij de oplossing van een vraagstuk gespeeld worden door de waarneming en de keuze tussen verschillende theorieën over het te behandelen onderwerp. In par. IV zal ik op de bijdrage van de filosofie ingaan.

De economie komt bij de beantwoording van ons vraagstuk te pas omdat een belangrijk deel van de verbanden die er bestaan tussen de lusten die het maatschappelijk verkeer mogelijk maakt en de lasten die het oplegt economische samenhangen zijn. Een centraal verband is dat tussen de inspanning die de meeste mensen in een samenleving zich moeten getroosten om een inkomen te verkrijgen, en dat inkomen. Voorts zijn ook de vraag hoe zij met dat inkomen hun behoeften trachten te bevredigen en wat de beste wijze is waarop dit kan, beide vraagstuklken die in de economie worden behandeld.

Bij een nadere beschouwing zal intussen blijken dat ook andere wetenschappen hebben mee te spelen. Een deel der menselijke behoeften is van biologische, een ander deel van sociologische aard en er kan aanleiding zijn om bij deze en nog andere wetenschappen te rade te gaan. De inspanning die de mens zich moet getroosten hangt o.m. van de toegepaste techniek van produceren af, hetgeen ons op het terrein van de techniek, dus de toegepaste natuur-, schei- en plant- en dierkunde, brengt; ook aan deze opsomming kunnen nog meer wetenschapsgebieden worden toegevoegd.

In zekere zin is het niet zo belangrijk, welke wetenschapsgebieden wel en welke niet in aanmerking komen voor de oplossing van een vraagstuk en dan ook het onze. De grenzen tussen de verschillende gebieden zijn historisch gegroeid, in veel opzichten willekeurig en 
bovendien veranderlijk. Het is dan hoofdzakelijk de vraag welke naar deze traditionele indeling gedefinieerde deskundigen zullen kunnen deelnemen aan het oplossingsproces. Dit proces behoudt daarbij de kenmerken van alle wetenschapsbeoefening die nader bezien zullen worden in par. IV.

\section{OBJECTIVITEIT: WEZEN EN GRENZEN}

Zoals al even aangeduid, is de in dit opstel te beschrijven poging er op gericht om te komen tot een meer objectieve bepaling van het begrip rechtvaardige verdeling. Het verlangen naar objectiviteit is de kenmerkende drijfveer geweest van alle wetenschappelijk werk. Zoals ook al even aangestipt, is het grote voordeel van dit streven gelegen in de mogelijkheden die objectiviteit opent om meningsverschillen en conflicten te overwinnen op een voor elke deelnemer aanvaardbare wijze - althans wanneer bij de anderen ook dat verlangen bestaat. Dit laatste vierde hoogtij sedert ongeveer $1800 \mathrm{en}$ is later in invloed afgenomen. Voor wie het tegengestelde verlangen mocht koesteren, is de meest georganiseerde en tevens afschuwwekkende poging om het instinct of de irrationaliteit weer tot methode van denken en handelen te maken leerzaam, nl. het optreden van Adolf Hitler. Het streven naar objectiviteit is daarom nog niet zo verwerpelijk als sommige tijdgenoten het gaarne voorstellen.

Toch is het goed om zich bewust te zijn van het wezen van objectieve stellingen, maar ook van de grenzen die aan het zoeken verbonden zijn. In de hoogtijdagen van de klassieke natuurkunde, leek de objectiviteit scherp definieerbaar en in absolute tegenstelling te staan tot de subjectiviteit, de intuitie of het toelaten van waardeoordelen, alles ook zaken waarvan de klassieke economist poogt zich verre te houden. De centrale gedachte van het objective kennen was dat het object waarop de studie zich richtte in zijn gedragingen voldeed aan één theorie, die door herhaalbare waarnemingen steeds weer bevestigd werd - hoogstens op kleine toevallige meetfouten na -, die binnen enge grenzen bleven en zelfs door verbetering der meetinstrumenten nog konden worden verminderd. In de taal van de maatschappelijke besluitvorming zou men kunnen zeggen dat elk onderdeel van deze procedure onderschreven werd door stemmingen onder de betrokkenen waarin geen tegenstemmers bestonden, dus 'met algemene stemmen'.

Sinds geruime tijd is echter de toestand in de natuurkunde niet 
meer zo. Daarbij doel ik niet eens op het erkennen van een principiële onnauwkeurigheid waarmee thans de metingen aan de kleinst bekende deeltjes behept zijn, waardoor de grens van de onnauwkeurigheid gevonden en overschreden is. Ik denk aan nog eenvoudiger en veel vroeger aanvaarde werkwijzen, bv. bij de invoering en meting van het begrip warmtegraad of temperatuur. De meting geschiedt door thermometers en is gebaseerd op de waarneming dat bij het achtereenvolgens toevoegen van gelijke hoeveelheden warmte de meeste stoffen onder de meeste omstandigheden gelijkmatig uitzetten. D.w.z. niet alle stoffen en voor elke stof niet onder alle omstandigheden. Water krimpt in als het verwarmd wordt van $0^{\circ}$ tot $4^{\circ} \mathrm{C}$; en elke stof kent veranderingen van vaste in vloeibare staat (bij het smeltpunt) en van vloeibare in gasvormige staat (bij het verdampingspunt). Men zou dat in de taal van de maatschappelijk besluitvorming kunnen uitdrukken door te stellen, dat bij elke temperatuur een grote meerderheid der stoffen 'stemt' over de temperatuursverhoging door toevoeging van een warmte-eenheid, maar niet alle stoffen 'stemmen vóór'. Er is dus geen volkomen objectiviteit, slechts een graad van objectiviteit.

In de sociale wetenschappen, waar er zoveel meer reden is om te geloven in het bestaan van subjectieve elementen, moet men daarom bij het zoeken naar objectiviteit niet eisen dat ooit een vaststelling van een grootte met algemene stemmen plaats vindt. Men zal tevreden moeten zijn met een 'ruime' meerderheid, waarbij het woord ruim zelf weer subjectief is.

Bovendien was het ook in de natuurkunde niet waar dat er over welk verschijnsel dan ook maar één theorie bestond. Er waren meestal wel meer theorieën mogelijk. Ik kom daarop zo dadelijk terug.

IV. METHODOLOGISCH OF FILOSOFISCH ASPECT VAN ONS VRAAGSTUK

Mijn voorstel tot definitie van rechtvaardige verdeling is dat het welzijn van alle in de beschouwde groep aanwezige personen eenzelfde hoogte heeft. Daarmee is het vraagstuk dus herleid tot dat van het meten van het welzijn, waaronder ik versta de bevrediging of het geluk, voorzover bepaald door de maatschappelijke toestand waarin ieder verkeert. Hierbij bedoelt de laatste beperking de zeer persoonlijke onstoffelijke componenten van het geluk, zoals bv. godsdienstige opvattingen en de verhoudingen van vriendschap of liefde, buiten de analyse te houden. Het vaststellen van de recht- 
vaardigheid eist dan, in de taal der economisten, het aanvaarden van een functie, in de zin van wiskundige formule, die het welzijn vaststelt in afhankelijkheid van een aantal in die formule voorkomende meetbare grootheden. In de economische wetenschap is deze functie ook bekend als de nutsfunctie - een iets te nuchtere en beperkte term - of als de door Pareto voorgestelde - neutraal bedoelde ophelimiteitsfunctie. Terwijl vrijwel alle economische scholen bij de opbouw van de economie van deze functie uitgaan, is men tevens veelal van mening dat zij niet meetbaar is. Mede om deze reden heeft CASsel er de voorkeur aan gegeven, haar niet als het fundament van zijn versie der economie te kiezen. Terwijl men haar inderdaad voor de oplossing van verreweg de meeste - tot nu toe behandelde vraagstukken niet nodig heeft, kan men haar voor het antwoord op ons probleem niet missen.

Het eerste methodologische vraagstuk waaromtrent ik een keuze wil voorstellen, is dat wij van de mogelijke theorieën ter verklaring van economische verschijnselen en processen de eenvoudigste kiezen, zolang de waarneming ons niet aantoont dat deze met de feiten in strijd is. Dan is het aannemen van meetbaarheid zonder twijfel eenvoudiger dan het aannemen van niet-meetbaarheid; en economisten als Frisch, Johansen en Barten hebben de meetbaarheid dan ook tot op zekere hoogte aangenomen.

Als tweede punt van methodologie stel ik voor, dat in de welzijnsfunctie drie soorten grootheden optreden, aan te duiden als variabelen, parameters en coëfficiënten. Zoals bij wiskundige functies gebruikelijk, zijn variabelen grootheden die hun waarde kunnen wijzigen; in ons geval zowel door de betrokken persoon zelf als door wat voor hem de buitenwereld is: andere personen, maatschappelijke instellingen en het natuurgebeuren. Tot de variabelen die in de nutsfunctie voorkomen reken ik dan in het bijzonder de kenmerken van de werkkring, bv. zoals deze door de werkclassificatie worden gedefinieerd, benevens andere omstandigheden waaronder de persoon - ten dele door eigen keuze - leeft, zoals arbeidsduur en -intensiteit, inkomen, belastingen en tenslotte de voor verbruik (eventueel van verschillende goederen- en dienstencategorieën) verrichte uitgaven. Tot de parameters worden gerekend een aantal grootheden die de persoon karakteriseren en in het algemeen voor één bepaalde persoon vastliggen, maar van de ene tot de andere persoon kunnen variëren. Tot deze parameters kan men rekenen een aantal eigenschappen die voor het maatschappelijk verkeer van belang zijn, bv. de eigen- 
schappen volgens de werkclassificatie benodigd om de werkzaamheden uit te oefenen waarvoor de betrokkene in aanmerking komt. Men kan daarbij denken aan intelligentie, handvaardigheid, samenwerkingsbereidheid, leiderschap en vele andere eigenschappen. Eveneens tot de parameters behoren de kenmerken van de behoeften van de betrokkene, zoals de grootte van haar of zijn gezin, elementen van smaak, gezondheid en behoeften verbonden aan de uitoefening van haar of zijn beroep. Terwijl omtrent een aantal der genoemde variabelen en parameters twijfel kan bestaan of zij reeds met voldoende nauwkeurigheid gemeten zijn, is er een algemene neiging om steeds meer te meten en zou als ik eis van wetenschappelijke behandeling van ons vraagstuk de noodzaak willen bepleiten om met deze meting steeds verder te gaan.

De laatste categorie der elementen van een welzijnsfunctie is die van de coëfficiënten. Deze geven aan hoe sterk en op welke wiskundige wijze de variabelen en de parameters het welzijn van de beschouwde persoon beïnvloeden. Aan de bepaling van de grootte der coëfficiënten moet voorafgaan een keuze van de wiskundige vorm der functie; voor de overgrote meerderheid der gevallen kan men deze echter ook zien als een bepaling van coëfficiënten, nl. in zoverre als de te gebruiken functie in een machtreeks te ontwikkelen is. Gemakshalve zal ik blijven spreken van coëfficiënten, zonder de keuze van de wiskundige vorm der functie steeds afzonderlijk te vermelden.

\section{ETHISCH OF MOREEL ASPECT VAN ONS VRAAGSTUK}

Zoals reeds even werd opgemerkt, is de ethische zijde van ons vraagstuk een zijde die boven het wetenschappelijke uit kan gaan. Dit houdt waarschijnlijk in, dat de mogelijkheid om hier een keuze te doen eerder kan leiden tot verdeeldheid tussen verschillende denkrichtingen dan dat in het zuiver wetenschappelijk deel van ons onderzoek het geval zal zijn. Hier komt het er dus nog meer op aan, een uitgangspunt te kiezen dat de grootste mogelijkheid heeft om door anderen te worden aanvaard. Ik meen dat aan deze voorwaarde wordt voldaan als als enig principe wordt gekozen dat van de 'fundamentele gelijkheid', ook wel genoemd dat van de 'gelijkwaardigheid' aller mensen. Dit beginsel wordt intussen pas duidelijk, wanneer aan de twee gebruikte aanduidingen een nauwkeuriger inhoud wordt gegeven. Deze inhoud kan het beste worden omschreven door 
te zeggen dat aangenomen wordt dat alle mensen in iedere zin gelijk worden beschouwd, behalve wanneer door meting, dat is door waarneming, kan worden vastgesteld dat zij ongelijk zijn. In vele opzichten - bv. lengte, gewicht, kennis, inzicht, bereidheid tot samenwerking - is reeds lang door meting vastgesteld dat de mensen niet allen gelijk zijn; en de mate van hun ongelijkheid kan worden vastgelegd in de waarden die eenzelfde parameter voor verschillende personen aanneemt. Telkens wanneer opnieuw de verdenking opkomt, dat de mensen in een bepaalde zin niet gelijk zijn, moeten wij daarvoor een parameter kiezen en de desbetreffende parameter voor alle beschouwde personen gaan meten. Weten wij niets omtrent ongelijkheid, dan veronderstellen wij gelijkheid. Wiskundig kunnen wij dit, aldus tewerk gaande, zó uitdrukken, dat de coëfficiënten van de welzijnsfunctie gelijk zijn voor allen; want als er ongelijke waren, dan zouden wij hen omdopen tot parameters. Kenmerkend voor de parameters is wel dat zij onveranderlijke, 'aangeboren' eigenschappen van de betrokkene aanduiden en geen gedrag dat door eigen keuze, al of niet onder invloed van de buitenwereld, kan worden gewijzigd. Het is bekend genoeg dat over de al of niet beïnvloedbaarheid van bepaalde eigenschappen nog vaak meningsverschil bestaat. ${ }^{2}$

De fundamentele gelijkheid of gelijkwaardigheid der mensen is, op deze wijze gerelativeerd, voor een grote meerderheid onder de mensen een aanvaardbaar ethisch principe. Telkens opnieuw zijn in de menselijke geschiedenis stromingen opgekomen die op de een of andere wijze gelijkheid als uitgangspunt hunner opvattingen en aktiviteiten kozen. Dit geldt voor verschillende grote godsdiensten, zowel als voor de Franse revolutie en voor de socialisten, ook wanneer men spottenderwijze bepaalde soorten socialisten als gelijker dan andere soorten aangeduid heeft. Het door de realiteit noodzakelijke relativeren van de gelijkheid is geschied zowel door dit laatste woord te vervangen door gelijkwaardigheid, als door toevoegingen als gelijk 'voor God', gelijk 'voor de rechter', of gelijk in het aanspraak kunnen maken op bepaalde verdere mensenrechten, waaronder kiesrecht, het recht van vrije meningsuiting enz. Naar het mij voorkomt, kan tegen mijn versie bijzonder weinig worden aangevoerd, omdat zij de deur openlaat voor elke verdere ongelijkheid die iemand zou willen

2 Ik vraag mij af, of wat $i k$ hier heb aangegeven als aangeboren eigenschappen wellicht overeenkomt met wat Duyker inwendige determinanten van menselijk gedrag noemt (vg1. H. C. J. Duyker, De meervoudige gedetermineerdheid van menselijk gedrag, Meded. der Kon. Ned. Akad. v. Wet., afd. Letterkunde, Nieuwe Reeks, Deel 35, no. 3, Amsterdam 1972). 
invoeren mits hij deze kan staven door waarnemingen. Deze 'omkering van de bewijslast' komt mij methodologisch volkomen verdedigbaar voor, omdat zij door de vereiste meting zal bijdragen tot de verdere ontwikkeling van de wetenschappelijke benadering. Het zal overigens ook duidelijk zijn, dat de eigenschappen die men in zijn beschouwingen opneemt, voor het op te lossen vraagstuk van de rechtvaardige verdeling relevant moeten zijn. Noch de kleur noch de lengte van iemands haar is hier relevant.

\section{EEN EENVOUDIG BEGIN VAN TOEPASSING}

In een tweetal onderzoekingen heb ik gepoogd een begin te maken met de toepassing van de in het voorgaande uiteengezette methode. Daarbij is aanvankelijk uitgegaan van slechts een parameter ter beschrijving van de relevante aangeboren eigenschappen, het vermogen om onderwijs te volgen, uitgedrukt in het daarbij behaalde peil. In het eerste onderzoek ${ }^{3}$ werd daarbij slechts verschil gemaakt tussen de drie niveau's die men aanduidt als primair, secundair en tertiair onderwijs. Aangenomen werd dat de bij de beroepsbevolking aanwezige niveau's konden worden afgelezen uit het opleidingspeil van de negen hoofd-beroepsgroepen die bij de Volkstelling van 1960 werden onderscheiden en van enige deelgroepen. Voor de door de maatschappij vereiste opleiding werd de bovenste quartiel van dezelfde opleidingscijfers genomen. Als een ruwe controle werd deze laatste vergeleken met de mediaan die men voor in 't algemeen vergelijkbare beroepsgroepen in de Amerikaanse Volkstelling aantreft. Er was geen systematisch verschil; gemiddeld was de Amerikaanse mediaan 1.6 jaar hoger dan de Nederlandse bovenste quartiel, doch de absolute afwijkingen bedragen gemiddeld ook 1.6.

Voor de wiskundige vorm van de welzijnsfunctie werd genomen:

$$
\omega_{h h^{\prime}}=\ln \left\{x_{h h^{\prime}}+\frac{1}{2} c_{0}(h-2)^{2}-\frac{1}{2} c_{2}\left(h-h^{\prime}\right)^{2}\right\}
$$

waarbij

$h$ het voor de beroepsklasse vereiste opleidingsniveau,

$h^{\prime} \quad$ het bij de betrokken personen aanwezige niveau,

$x_{h h^{\prime}}$ het arbeidsinkomen na betaling van directe belastingen, en

$\omega_{h h^{\prime}}$ het welzijn van de beschouwde groep aangeeft.

3 Jan Tinbergen, Income Distribution over Educational Levels: a Simple Model, nog te verschijnen. Voorlopig beschikbaar als stencil JT/SvW/1-9-1972/28 bij het Nederlands Economisch Instituut, Rotterdam. 
Aangenomen is dus dat dit welzijn de logarithme is van de uitdrukking tussen \{\} , die men zou kunnen noemen het besteedbare inkomen, gecorrigeerd voor (a) de bevrediging die het uitoefenen van het beroep $h$ meebrengt en (b) de tegenzin die het uitoefenen van een beroep $h$ meebrengt voor iemand met een opleiding $h^{\prime}$. Deze laatste grootheid is de enige parameter die de voor de betrokken groep de 'sociale kwaliteit' beschrijft; de variabelen zijn $x_{h h^{\prime}}$ en $h$, terwijl de enige coefficiënten $c_{0}$ en $c_{2}$ zijn. Bij meting van $h$ en $h^{\prime}$ door de getallen 1,2 en 3 en de getallen $x_{h h^{\prime}}$ in duizenden guldens per jaar (omstreeks 1960-1966) werden voor de coëfficiënten de waarden gevonden:

$$
\begin{aligned}
& c_{0}=0,63 \\
& c_{2}=2,84
\end{aligned}
$$

De kwadratische vorm van de beide correcties op het besteedbare inkomen betekent dat de beroepsbevrediging het geringste is voor de groep met een secundaire opleiding en zowel voor de groep met een lagere als voor die met een hogere opleiding groter is. Anders gezegd vermindert de arbeidsvreugde van niveau 1 naar niveau 2 (voor mensen met dezelfde opleiding) en vermeerdert zij tussen niveau 2 en niveau 3. De tweede term zegt dat bij een gegeven opleiding $h^{\prime}$ men zich het prettigste voelt in een beroep dat juist die opleiding vereist en minder plezierig, wanneer men òf wel in een 'lager', òf wel in een hoger beroep terechtkomt.

Voorzover men de theorie en de metingen aanvaardt - over een aantal uitvoerbare verbeteringen zal hierna nog uitvoeriger worden gesproken - zou een rechtvaardige inkomensverdeling eisen dat $x_{11}=x_{33}$, terwijl zij nu resp. 5.7 en 14.0 zijn, terwijl $x_{22} 0.315$ hoger zou moeten zijn dan $x_{11}$ en $x_{33}$. Groepen die een beroep $h$ uitoefenen dat 1 punt hoger ligt dan hun opleiding, zouden bij een rechtvaardige inkomensverdeling 1.42 meer moeten verdienen (na belasting), terwijl deze verschillen in feite voor $h=1$ resp. 2 bedragen 5.0 en 2.1 .

\section{TWEEDE, IETS MINDER VEREENVOUDIGDE POGING}

Het tweede hier te vermelden, eveneens nog uiterst vereenvoudigd, voorbeeld 4 is gebaseerd op een verdeling van de beroepsbevolking in

4 Jan Tinbergen, An Interdisciplinary Approach to the Measurement of Utility or Welfare, Geary Lectuve $197^{2}$ (Stencil J T/SvW/18-8-1972/25 bij het Nederlands Economisch Instituut, Rotterdam). 
19 groepen, waarbij zowel het aanwezige als het vereiste opleidingsniveau op dezelfde wijze geschat werden als in het cerste voorbeeld, doch waarbij vijf opleidingsniveau's werden onderscheiden. In eenheden van 3 jaar schoolgaan werden $h$ en $h^{\prime}$ door de cijfers van 2 (lagere school) tot en met 6 (universitaire opleiding) aangegeven. $\mathrm{Bij}$ dit verfijnde materiaal bleek het niet mogelijk om de waargenomen verschillen in $x$ (arbeidsinkomen na directe belastingen) bevredigend te verklaren door rekening te houden met alleen de parameter $h^{\prime}$. De daarmede verkregen correlatiecoëfficiënt was 0.14 en de regressiecoëfficiënt voor de termen met $h$ niet-significant. De eenvoudigste theorie moest dus verworpen worden en vervangen worden door een meer ingewikkelde. Dit bleek goed mogelijk te zijn door een tweede parameter $W$ in te voeren, die op grove wijze de graad van onafhankelijkheid van het beroep weergeeft. Deze parameter werd de waarde 2 gegeven voor directeuren van N.V.'s en zelfstandigen in de vrije beroepen, 1 voor onafhankelijken in industrie, handel en diensten en docenten bij het secundair en tertiair onderwijs, en 0 voor alle andere groepen, waaronder ambtenaren, employé's, onderwijzers en boeren. Op deze wijze werd een beroepsbevolking in drie groepen verdeeld van verschillende graad van onafhankelijkheid. Binnen elk daarvan werden dan weer groepen met een gegeven opleidingsniveau $h^{\prime}$ genomen, die in verschillende beroepen $h$ werkten en uit deze vergelijking kon de invloed van de $h$ op $\omega$ worden geschat. Nu werd gevonden:

$$
\omega_{h h^{\prime}}=\ln \left\{x_{h h^{\prime}}-0,45 h-0,32\left(h-h^{\prime}\right)^{2}\right\}
$$

Dit houdt in dat volgens dit resultaat de bevrediging geschonken door min de last verbonden aan een 'hoger' beroep nu minder is dan bij een 'lager' beroep. Als men echter de 'bovenste' helft van de beroepsbevolking beschouwt, vindt men dat de bevrediging het van de inconveniënten wint en in zoverre was de formule (1) misschien beter dan (4). Wat de invloed van de uitoefening van een beroep, niet in overeenstemming met de genoten opleiding, betreft, moet men bedenken dat de eenheden, waarin nu de $h$ en de $h^{\prime}$ zijn gemeten, half zo groot zijn als in (1); daardoor zou men, om de coëfficiënt 0,32 vergelijkbaar te maken met de 1,42 gevonden in (1), de eerstgenoemde met 4 moeten vermenigvuldigen, waardoor 1,28 wordt verkregen: een bevredigende overeenstemming. 
VIII. DE ROL VAN DE PARAMETERS BIJ DE INTERPERSONELE WELZIJNSVERGELIJ KING

De kern van de voorgestelde werkwijze is dat men mensen vergelijkt met gelijke parameters en deze zijn het ook alleen die men kan vergelijken, omdat zij een vrije keuze hebben om hun variabelen, in onze voorbeelden alleen nog beroep en inkomen, te kiezen. ${ }^{5}$ Men zou weliswaar als waarnemingen ook de inkomens en parameters kunnen gebruiken van mensen met verschillende parameters, en aldus formules kunnen toetsen, waarin behalve de in (1) en (4) voorkomende ook termen in $h^{\prime}$ en $W$ alleen zouden zijn opgenomen. Dit is trouwens in het tweede voorbeeld (par. 7) gedaan, waarbij hoge regressiecoëfficiënten, en wel negatieve, voor $W$ werden gevonden; hetzelfde is het geval voor $h^{\prime}$ voor de 'bovenste' helft van de beroepsbevorking. Dit betekent dat groepen met een hogere $W$ een (vrij veel) hoger inkomen hebben dan die met een lagere, en iets dergelijks voor $h^{\prime}$. Dit mag echter niet zo worden verstaan dat deze inkomensverschillen rechtvaardig zijn; het geeft in hoofdzaak de invloed van de schaarste van deze eigenschappen aan. Men kan integendeel aannemen dat een hogere $W$ en een hogere $h^{\prime}$ aan hun bezitters positieve voldoening schenken en dat zij bij een rechtvaardige inkomensverdeling eerder minder dan meer inkomen moeten hebben dan de bezitters van een lagere $W$ of $h^{\prime}$. Daarom maakt het weglaten van termen met $W$ of $h^{\prime}$ in (4) en (1), dat wat wij als rechtvaardige inkomensverdeling hebben aangegeven eerder nog iets te gunstig is voor begaatden; niettemin vinden wij ook uit formule (4) dat een rechtvaardige inkomensverdeling als volgt zou zijn, vergeleken met de werkelijke (uiteraard een slechts zeer voorlopige illustratieve uitkomst):

Tabel 1. Werkelijke en rechtvaardige () inkomens in $f 1000,-$ (Nederland 1960/6).

\begin{tabular}{rcrrrr}
\hline$h$ & $h^{\prime}=2$ & 3 & 4 & 5 & 6 \\
\hline 6 &. & & $14,0(9,7)$ & $14,0(8,7)$ & $14,0(8,4)$ \\
5 & $\cdot$ & $11,3(9,2)$ & $11,3(8,3)$ & $11,3(8,0)$ & $11,3(8,3)$ \\
4 & $8,3(8,8)$ & $8,3(7,8)$ & $8,3(7,5)$ & $8,3(7,8)$ & $8,3(8,8)$ \\
3 & $9,9(7,4)$ & $10,2(7,1)$ & $10,5(7,4)$ & $10,8(8,3)$ &. \\
2 & $4,9(6,6)$ & $7,7(6,9)$ &. &. &. \\
\hline
\end{tabular}

5 Dit was kennelijk ook wat mogelijk blijft van het door Ehrenfest voorgestelde en door mij in vroegere geschriften overgenomen 'ruilbeginsel'. Zie mijn Redelijke inkomensverdeling, Haarlem 1946. 
De enige wijze waarop parameters wel verschijnen in onze welzijnsfunctie is die waarbij aangenomen wordt (en m.i. moet worden), dat een van te voren gekozen combinatie van $h$ en $h^{\prime}$ het welzijn beïnvloedt, zoals in onze theorieën het verschil of de 'spanning' $h-h$ '. Zoals uit het voorgaande is gebleken, wordt deze theorie door de feiten niet geloochenstraft; waardoor overigens haar juistheid ook niet bewezen wordt.

\section{SCHIJNBARE EN ECHTE PARAMETERS}

In onze eenvoudige voorbeelden hebben wij, voor demonstratiedoeleinden, aangenomen dat het aantal jaren voltooid onderwijs $h^{\prime}$ en de graad van zelfstandigheid ( $W$ of $W^{\prime}$ ) als echte parameters in onze zin (zie par. 5) kunnen worden beschouwd. Dit is duidelijk een oververeenvoudiging. Voor wat betreft het aantal jaren voltooid onderwijs moet men eigenlijk aannemen dat het de uitkomst is van een keuzeproces, waarbij als echte parameters wellicht de aangeboren intelligentie en het beroep van de vader naast de variabelen zoals de inkomensschaal en de kosten van het onderwijs zijn opgetreden. Het aantal jaren onderwijs is dus maar een schijnbare parameter, of een plaatsvervangende (dummy). Een diepergaande studie zal als parameters de zojuist genoemde 'echte' moeten gebruiken.

Voor wat de graad van zelfstandigheid betreft, kan bovendien nog een andere vraag gesteld worden. Indien zij geen echte parameter zou zijn, kan zij dan worden aangeleerd en zo ja, hoe? Als een der pogingen om op deze vraag een antwoord te geven, werd in onze tweede studie aangenomen dat, evenals t.a.v. het vereiste aantal schooljaren aan het beroep verbonden, zelfstandigheid kon worden bevorderd door een langere schoolopleiding. D.w.z. dat ook hier een spanning $W-\beta h^{\prime}$ (waarbij $\beta$ een onbekende coëfficiënt is die aan zou geven met welke intensiteit een eenheid $h^{\prime}$ de geschiktheid van de betrokken groep voor een beroep met een eenheid meer $W$ zou verhogen) invloed op de bevrediging zou vertonen. De berekeningen wezen uit dat deze nieuwe theorie weinig tot de verklaring der waargenomen inkomensverschillen kon bijdragen en overigens in de tegenovergestelde richting. Het verlengen van het schoolgaan werkte eerder andersom, hetgeen velen niet zal verbazen. Men kan dit ook zó interpreteren, dat het complement op de tijd van schoolgaan, nl. de tijd van ervaring in de praktijk, de graad van zelfstandigheid verhoogt, hetgeen aannemelijker klinkt. Zonder deze laatste para- 
meter - de duur van de ervaring - in te voeren kon men beter vooralsnog de graad van zelfstandigheid als een aangeboren eigenschap (dus parameter) beschouwen.

Bij een splitsing van het statistisch materiaal zou een andere parameter, kenmerkend voor de behoeften, kunnen worden ingevoerd, $\mathrm{nl}$. de grootte van het gezin, zoals deze al in vroeger theoretisch werk ${ }^{6}$ was gebruikt. Op korte termijn gezien kan de gezinsgrootte inderdaad als een echte parameter worden aanvaard. Op langere termijn is echter ook hier sprake van een schijnbare parameter, omdat geboorteregeling binnen het vermogen van de mens ligt, en de uitkomst mede beïnvloed wordt door voorlichting op dit gebied en de beschikbaarheid van middelen tot verhindering van zwangerschap.

$X$. DE WENSELIJKHEID VAN HET INVOEREN VAN VEEL MEER PARAMETERS

Wil men van de werkelijkheid een nauwkeuriger beeld bezitten en daardoor de hier voorgestane theorie op veel nauwkeuriger wijze toetsen, dan dient een aanmerkelijk groter aantal parameters te worden ingevoerd. Men kan hier denken aan een aantal parameters corresponderend met het aantal aspecten dat bij de werkclassificatie wordt gebruikt ter kenschetsing van een beroep. Zulke aspecten zijn, zoals reeds opgemerkt, behalve intelligentie, ook doorzettingsvermogen, handvaardigheid, houding tegenover medewerkers of tegenover klanten enz. enz. T.a.v. alle tegenwoordig belangrijk geachte aspecten zou dan ook een steekproef van de bevolking moeten worden 'gemeten', d.w.z. de mate waarin elk aspect bij elke persoon in de steekproef aanwezig is, uitgedrukt in dezelfde eenheden als in de werkclassificatie worden gebruikt ter beschrijving van de beroepen. ${ }^{7}$ Hier ligt een enorm onderzoeksgebied braak, dat op het ogenblik niet bewerkt is, doch wellicht zou kunnen worden bewerkt met behulp van de gegevens die voor de loopbaanplanning in een aantal bedrijven en diensten worden verzameld, doch nog niet statistisch verwerkt door bv. het Centraal Bureau voor de Statistiek. Naar onze mening zou een dergelijke verwerking, zij het aanvankelijk als een proefonderzoek, van veel belang zijn voor het beantwoorden van de vraag naar de rechtvaardigheid der inkomensverdeling. Bovendien

6 Jan Tinbergen, A Positive and a Normative Theory of Income Distribution, The Review of Income and Wealth, serie 16 (1970), p. 221.

$7 \mathrm{Ik}$ denk hier mede aan wat door Ph. J. Idenburg in De Utopie in het onderwijsbeleid, Groningen 1972, 'andere aspecten van de menselijke geest' genoemd worden. 
zou zulk materiaal ook kunnen worden gebruikt ter benaderde oplossing van het vraagstuk van de optimale sociale orde. Met dit laatste vraagstuk is dan bedoeld ${ }^{8}$ aan te geven, welke instellingen voor produktie, onderwijs, belastingheffing en de uitvoering van andere taken tezamen kunnen leiden tot het hoogste peil van welzijn voor de bevolking als geheel, waarbij men als nevenvoorwaarde ook nog een rechtvaardige inkomensverdeling kan toevoegen; òf men dit laatste wil doen, is een element van keuze voor de gemeenschap en behoeft niet in het optimumbegrip te worden inbegrepen.

Ook reeds voor onze beide eenvoudige voorbeelden (paragrafen 6 en 7) zou een werkelijke directe meting van de vereiste en de werkelijke eigenschappen $h$ en $h^{\prime}$ een flinke stap voorwaarts betekenen. Men kan daarbij denken aan het verzamelen van gegevens, voor een representatieve steekproef van onze samenleving, over de voor elk beroep vereiste en de door de beoefenaren van dat beroep behaalde diploma's e.d.

Het onderzoek zou voorts verfijnd kunnen worden door de besteedbare inkomens $x_{h h^{\prime}}$ nog te vermeerderen met de inkomens in natura voortvloeiend uit de levering beneden kostprijs van bepaalde diensten aan bepaalde bevolkingsgroepen door de gemeenschap. Tenslotte zou men dichter in de buurt komen van de traditionele belangstelling van de economische wetenschap als men in plaats van het besteedbare inkomen de verbruikte hoeveelheden van een aantal goederen en diensten afzonderlijk zou invoeren. Naar mijn smaak zijn dit echter vraagstukken van minder belang dan de hier behandelde. In andere woorden meen ik dat het differentiëren van onze bevolking naar opleidings- en beroepsgroepen en naar grootte van gezin aanmerkelijk belangrijker is dan het differentiëren naar de hoeveelheden van een aantal goederensoorten die door de gezamenlijke bevolking worden verbruikt.

\section{Summary}

An Approach to the Measurement of a Just Distribution of Income

The author proposes a method to arrive at a cardinal theory of utility or welfare (considered identical) by the introduction into the utility function of (1) variables, (2) parameters and (3) coefficients. Parameters

8 Zie het in ${ }^{4}$ aangehaalde artikel. 
characterize measured differences between individuals relevant to the problem considered; variables indicate either choices open to individuals (job, income) or exogenous circumstances (a salary scale or a tax scale). The ethical postulate introduced is the equality of each coefficient among different individuals, offered as an interpretation of the 'fundamental equality of men'. Once the utility function has been defined and tested, justice in distribution is defined as equality of the values of that function for all individuals considered. A numerical illustration is added in which years of schooling and degree of independence are used as parameters to characterize twenty social groups and the just as distinct from the actual income distribution is calculated for the Netherlands around 1965. 